\title{
Evaluation of amphetamine-type stimulant abuse through hair analysis: Results from 12 years of work
}

\author{
Irena Brčić Karačonji and Nataša Brajenović \\ Analytical Toxicology and Mineral Metabolism Unit, Institute for Medical Research and Occupational Health, Zagreb, \\ Croatia
}

Received in March 2014

CrossChecked in March 2014

Accepted in June 2014

\begin{abstract}
Hair analysis is a reliable tool for detecting long-term exposure to illegal drugs, including amphetaminetype stimulants, over periods from a few weeks to a few months, depending on the length of the hair used for analysis. Between 2000 and 2012, over 600 hair samples were analysed at the Institute for Medical Research and Occupational Health, Croatia (IMROH) for the presence of amphetamine-type stimulants. IMROH has used the same procedure for testing hair samples for amphetamine-type stimulants for over twelve years. It was found to be reliable for confirming repeated abuse of amphetamine-type stimulants. Gas chromatography/mass spectrometry (GC/MS) was used to determine amphetamine, methamphetamine, 3,4-methylenedioxyamphetamine (MDA), 3,4-methylenedioxymethamphetamine (MDMA-Ecstasy), and 3,4-methylenedioxyethylamphetamine (MDEA) in hair. Hair samples were either taken at the Institute, delivered by mail or a third person brought them to the laboratory. In most cases, the hair samples were tested anonymously. A total of $23 \%$ of the tested samples were positive for one or more amphetamine-type stimulant. MDMA was the most frequently detected substance, whereas the most frequent combination was amphetamine with MDMA. Our results could indicate a trend in amphetamine-type stimulant abuse among young people in the Republic of Croatia.
\end{abstract}

KEY WORDS: GC/MS; MDMA; methamphetamine; quantitative determination

Amphetamine-type stimulants usually refer to synthetic substances like amphetamine, methamphetamine, 3,4-methylenedioxymethamphetamine (MDMA-Ecstasy), 3,4-methylenedioxyamphetamine (MDA), and 3,4-methylenedioxyethylamphetamine (MDEA) that act as central nervous system stimulants. According to data provided by the European Monitoring Centre for Drugs and Drug Addiction (1), approximately one quarter of Europe's adult population have used an illicit drug at some point in their lives and approximately $3.8 \%$ of all Europeans aged 15-64 have consumed amphetamines at least once in their lifetime (2). A study conducted by the Ivo Pilar Institute of Social Science on illicit drug use in the general Croatian population $(4,756$ respondents) showed that $16 \%$ of adults aged 15-64 reported taking at least one type of drug of abuse in their lifetime (3). Amphetamine-type stimulants are the second most frequently used illicit drugs after cannabis: the lifetime prevalence of taking cannabis in Croatia is $15.6 \%$, followed by amphetamines $(2.6 \%)$ and ecstasy $(2.5 \%)$. The main concern is the higher lifetime prevalence (25.7\%) of taking an illegal drug among the 15-34 age group. In the same age group, the lifetime prevalence rate of taking amphetamine-type stimulants was two times higher than among all adults (aged 15-64). Around $23 \%$ of respondents who had taken an amphetaminetype stimulant at least once reported their first experience with these illegal drugs at an age between 16 and 17 . The second main concern is that, after years of declines in the quantity of amphetamine-type 
stimulants seized, a rise was recorded in 2011 (4). In a comprehensive study performed in a Zagreb wastewater treatment plant in 2009, a consumption of 1-3 kg per year amphetamine-type stimulants was estimated based on their analysis in wastewater. The authors concluded that the amphetamine-type drug consumption rate in the city of Zagreb $(3.6-9.7 \mathrm{mg}$ per day in 1000 inhabitants) is comparable to that in Italy and Switzerland, but significantly lower than in UK and Spain (5).

Due to the abovementioned reasons, the early identification of drug abuse in the general population is critical in planning preventative action and reducing the damage caused by illicit drug use. Unlike urine, in which the generally accepted detection time for amphetamine-type stimulants is 1 to 3 days, hair provides information on long-term exposure to amphetamine-type stimulants over a period from a few weeks to a few months, depending on the length of the hair collected (6).

Since 2000, the Institute for Medical Research and Occupational Health in Zagreb, Croatia (IMROH) has provided quantitative hair analyses for amphetaminetype stimulants for a wide variety of customers including private customers, addiction prevention centres, hospitals, courts, and employers. The aim of this paper is to provide an overview of amphetaminetype stimulant abuse in Croatia, as well as to evaluate the different characteristics of the hair samples analysed at the Institute with regard to how and from whom they were received.

\section{MATERIALS AND METHODS}

\section{Hair samples}

Hair samples $(\mathrm{n}=666)$ from various sources were received or taken in the laboratory. A strand of hair of approximately $5 \mathrm{~mm}$ in diameter was cut from close to the scalp at the vertex posterior area, folded in aluminium foil or paper, and the proximal and distal ends were marked. We analysed hair segments $2-4 \mathrm{~cm}$ long from the proximal end, which represent approximately 2-4 months of hair growth as stated in the literature (7). The study was conducted according to the ethical standards of the Helsinki Declaration and was approved by the IMROH Ethics Committee. The investigation presented in this paper was performed within a wider research project entitled
"Identification of drug abuse by comparative analysis of biological specimens" and funded by the Ministry of Science and Technology of the Republic of Croatia.

\section{Hair analysis}

Hair samples were analysed according to a previously validated procedure (8). The gas chromatography/mass spectrometry (GC/MS) method was developed for determining amphetamine, methamphetamine, MDMA, MDA, and MDEA in hair. Over the years, a few procedural modifications were done (reagent and standard suppliers were changed and deuterated internal standards were purchased). All of the changes were fully validated before routine laboratory work. In brief, the hair was washed in dichloromethane, dried, cut into very small pieces, and $50 \mathrm{mg}$ of hair was used for analysis. Hair samples were submitted to alkaline digestion with $1 \mathrm{~mol} \mathrm{~L}^{-1}$ sodium hydroxide at $70{ }^{\circ} \mathrm{C}$ for 20 min prior to extraction with ethyl acetate $(2 \times 1 \mathrm{~mL})$. The extract was evaporated to dryness in the presence of a $100 \mu \mathrm{L}$ mixture of methanol:hydrochloric acid $(99: 1, \mathrm{v} / \mathrm{v})$ to prevent a loss of volatile amphetamine and derivatizated with $50 \mu \mathrm{L}$ of heptafluorobutyric anhydride (HFBA) at $60{ }^{\circ} \mathrm{C}$ for $30 \mathrm{~min}$. The derivatizated samples were evaporated to dryness, and reconstituted in $100 \mu \mathrm{L}$ of ethyl acetate for injection of $1 \mu \mathrm{L}$ onto a gas chromatograph Varian 3400 CX with Saturn ion trap mass spectrometer equipped with HP-5MS capillary column (5\% diphenyl-95 \% dimethylpolysiloxane, $30 \mathrm{~m}, 0.25 \mathrm{~mm}$ ID, $0.25 \mu \mathrm{m}$ film thickness; J\&W Agilent Technologies; Santa Clara, USA). Three ions for the analytes and two ions for the internal standards were monitored in the selected ion monitoring (SIM) mode. The following ions were used for each drug: amphetamine-HFBA， $m / z \quad 240,118,91$; methamphetamine-HFBA, $m / z$ 254, 210, 118 ; MDAHFBA, $m / z$ 135, 162, 240; MDMA-HFBA, $m / z$ 162, 254, 210; MDEA-HFBA, $m / z$ 268, 135, 162; amphetamine-d $\mathrm{d}_{5}$-HFBA, $m / z 244,92$; and MDMA-d $\mathrm{d}_{5}-$ HFBA, $m / z 258,165$. The underlined ions were used for quantitation. The standards were prepared in blank hair extracts. Each case sample batch included standards and positive and negative control. The precision expressed as relative standard deviation (RSD) was $<9 \%$ and the accuracy was $>85 \%$ for all of the 5 analytes. The limit of detection ranged from $0.01 \mathrm{ng} \mathrm{mg}^{-1}$ to $0.05 \mathrm{ng} \mathrm{mg}^{-1}$. The confirmation cut-off for amphetamine-type stimulants was $0.2 \mathrm{ng} \mathrm{mg}^{-1}$. External quality assessment was performed through participation in the Proficiency Testing programme 
organised by the Society of Hair Testing (9). For the purpose of this study, all data above the limit of detection were included.

\section{RESULTS AND DISCUSSION}

During the period from 28 April 2000 to 10 December 2012, 666 hair samples were analysed. A large majority of our customers were parents who had suspected their children of taking drugs - primarily amphetamine-type stimulants. In most instances, a third person (e.g., parent) brought the hair sample for analysis $(40 \%)$. In other cases, hair samples were taken at IMROH by trained personnel $(37 \%)$ or delivered by mail (23\%). In $73 \%$ of cases, hair samples were tested anonymously (e.g., the hair samples were received under only the first or a fictitious name, or a number). Hair analysis requests from private customers accounted for approximately $92 \%$ of the total number of samples. Less than $8 \%$ of cases included hair samples tested for official purposes [addiction prevention centres and hospital requests (3.8\%), workplace drug testing $(2.7 \%)$, and court proceedings $(1.4 \%)$ ]. The probable reason for such a low percentage of official requests in Croatia compared to e.g. United Kingdom (10) is that hair testing for illegal drugs has not yet been included in any Croatian law or regulation.

The main drawbacks in case of sampling hair from a third person are the lack of control regarding protocols and the ability to collect hair "next to the scalp". LeBeau et al. (11) suggested that, beside the variability in the growth rate, inconsistent collection may have an important impact on the interpretation of results.

Among customers who could be identified by gender (they came personally to the laboratory) males were more likely to be positive ( $23 \%$ of positive males vs. $17 \%$ of positive females), which is in accordance with studies by Strote at al. (12), Martins et al. (13), and Molinaro et al. (14), who reported a higher prevalence of illegal drug use among males. Also, males were 2.5 times more frequent clients compared to females.

Table 1 summarises the positive results of hair testing ( $\mathrm{n}=155)$, in which one or more type of drug were found. A total of $23 \%$ of the tested samples were positive for one or more amphetamine-type stimulant. Among the hair samples received, $25 \%$ of samples from users who provided their identity tested positive compared to $20 \%$ of positive hair samples received anonymously. Considering single drug use, MDMA was the most frequent detected substance (in $10 \%$ of the samples), followed by amphetamine (5\%). The most frequent combination was amphetamine with MDMA (5\% of all hair samples). Methamphetamine was detected in only $1 \%$ of hair samples. In less than $2 \%$ of hair samples, we detected methamphetamine + MDMA, amphetamine + methamphetamine, amphetamine + methamphetamine + MDMA or amphetamine + MDMA + MDA + MDEA.

According to surveys conducted on a large sample size in Norway (15), Australia (16), United States (13),

Table 1 Distribution of positive hair samples $(n=155)$ based on the presence of certain amphetamine-type stimulants and their combinations in the 2000-2012 period

\begin{tabular}{lc}
\hline Amphetamine-type stimulant(s) in hair samples & Number of positive samples \\
\hline MDMA $\left(+\mathrm{MDA}^{\mathrm{a}}\right)$ & 64 \\
\hline Amphetamine+MDMA $\left(+\mathrm{MDA}^{\mathrm{a}}\right)$ & 36 \\
\hline Amphetamine & 34 \\
\hline Methamphetamine & 9 \\
\hline Methamphetamine+MDMA(+MDA $)$ & 5 \\
\hline Amphetamine+Methamphetamine & 3 \\
\hline Amphetamine+Methamphetamine+MDMA & 3 \\
\hline Amphetamine+MDMA+MDA+MDEA & 1 \\
\hline
\end{tabular}

anot detected in all samples; MDMA - 3,4-methylenedioxymethamphetamine;

$M D A$ - 3,4-methylenedioxyamphetamine; MDEA - 3,4-methylenedioxyethylamphetamine 
and Taiwan (17), MDMA appeared to be the most commonly used illegal drug in adolescents and young adults. The prevalence of MDMA in our study was not surprising since most of our clients were adolescents and young adults considered to be frequent consumers of MDMA. In addition, MDMA is easily available and relatively cheap. Growing concerns have been raised about ecstasy use during adolescence because young ecstasy users tend to be more naive and more vulnerable to the harmful effects. The small number of samples positive for methamphetamine could be explained by its low accessibility and relatively high price (4). The levels detected for amphetamine-type stimulants are presented in Table 2.

The measured concentrations were in accordance with already published concentration ranges $(10,18$, 19). Among the 109 cases positive for MDMA, its metabolite MDA was detected in 23 cases. The MDA/ MDMA ratio in hair ranged from 0.01 to 0.25 , which was in agreement with earlier observations (20). In most of the MDMA positive samples (73.4\%), MDMA was found in mass fractions up to $5.0 \mathrm{ng} \mathrm{mg}^{-1}$, which is in accordance with previously reported results (21). Amphetamine was found in 77 cases, 36 of which exhibited a co-occurrence with MDMA, which is generally the most frequent combination. The probable reasons for the wide range of mass fractions for amphetamine and MDMA could be the different purity, frequency, and amount consumed. Also, the different hair treatments in $10 \%$ of the analysed hair samples could be the reason for a slight decrease of drug content in those hair samples, which has been documented by several authors $(18,22,23)$.

Interpretation of hair analysis results is a very challenging process due to several possible sources of error. In addition to different hair growth rate and errors in sampling, a possible problem in hair analysis could be false positive hair testing result caused by passive exposure to drug from the environment. Therefore, a decontamination step using appropriate solvents is necessary prior to the analysis of hair samples (24). In addition, another problem is the lack of correlation between frequency of drug use and its concentration in hair due to the different incorporation rate of drug in the hair, different hair melanin content, use of hair treatments (bleaching and dyeing), etc. Pharmacogenetic variations also play an important role in the interpretation of hair analysis results (25).

\section{CONCLUSIONS}

It is evident that hair is a reliable biological marker for cumulative exposure to illicit drugs. IMROH has used the same hair sample testing procedure for amphetamine-type stimulants for over twelve years. This method was found to be reliable for confirming repeated amphetamine-type stimulant abuse. Our study can serve to provide a preliminary idea about the trend of amphetamine-type stimulant abuse among adolescents and young adults in Croatia.

\section{Acknowledgements}

Author's attendance of the TIAFT2013 Congress (where this study was presented) was supported by a donation from Biovit, Croatia. The authors also wish to thank Ms Vesna Triva for her most skilful technical assistance.

Table 2 Mass fraction of certain analytes determined in hair samples

\begin{tabular}{ccc}
\hline \multicolumn{1}{l}{ Analyte } & Number of positive samples & $\begin{array}{c}\text { Mass fraction (ng mg-1) } \\
\text { median (range) }\end{array}$ \\
\hline MDMA & 109 & $2.30(0.45-90.8)$ \\
\hline Amphetamine & 77 & $1.51(0.15-118.7)$ \\
\hline MDA & 23 & $0.81(0.18-4.64)$ \\
\hline Methamphetamine & 20 & $0.67(0.10-2.01)$ \\
\hline MDEA & 1 & $2.13(-)$ \\
\hline
\end{tabular}

MDMA - 3,4-methylenedioxymethamphetamine; $M D A$ - 3,4-methylenedioxyamphetamine;

MDEA - 3,4-methylenedioxyethylamphetamine 


\section{REFERENCES}

1. European Monitoring Centre for Drugs and Drug Addiction (EMCDDA). European Drug Report 2013. Trends and developments [displayed 6 June 2014]. Available at http:// www.emcdda.europa.eu/publications/edr/trendsdevelopments/2013

2. European Monitoring Centre for Drugs and Drug Addiction, Europol. EMCDDA-Europol joint publications No 3. Amphetamine: A European Union perspective in the global context; 2011 [displayed 6 June 2014]. Available at http:// www.emcdda.europa.eu/attachements.cfm/att_145911_EN_ EMCDDA-Europol_Amphetamine-joint-publication.pdf

3. Glavak Tkalić R, Miletić GM, Maričić J, Wertag A. Substance abuse among the general population in the Republic of Croatia: Research Report. Zagreb: Institute of Social Sciences Ivo Pilar and Government of the Republic of Croatia - Office for Combating Drug Abuse; 2012.

4. European Monitoring Centre for Drugs and Drug Addiction (EMCDDA). 2012 National Report (2011 data) to the EMCDDA by the Office for Combating Drugs Abuse of the Government of the Republic of Croatia [displayed 6 June 2014]. Available at http://www.uredzadroge.hr/en/ files/2013/06/Cro_Report_en2012.pdf

5. Terzic S, Senta I, Ahel M. Illicit drugs in wastewater of the city of Zagreb (Croatia) - Estimation of drug abuse in a transition country. Environ Pollut 2010;158:2686-93. doi: 10.1016/j.envpol.2010.04.020

6. Vincenti M, Salomone A, Gerace E, Pirro V. Application of mass spectrometry to hair analysis for forensic toxicological investigations. Mass Spectrom Rev 2013;32:312-32. doi: 10.1002/mas. 21364

7. Pötsch L. A discourse on human hair fibers and reflections on the conservation of drug molecules. Int J Legal Med 1996;108:285-93. doi: 10.1007/BF02432122

8. Skender L, Karačić V, Brčić I, Bagarić A. Quantitative determination of amphetamines, cocaine, and opiates in human hair by gas chromatography/mass spectrometry. Forensic Sci Int 2002;125:120-6. doi: 10.1016/S03790738(01)00630-2

9. Cooper GAA, Kronstrand R, Kintz P. Society of Hair Testing guidelines for drug testing in hair. Forensic Sci Int 2012;218:20-4. doi: 10.1016/j.forsciint.2011.10.024

10. Tsanaclis L, Wicks JFC. Patterns in drug use in the United Kingdom as revealed through analysis of hair in a large population sample. Forensic Sci Int 2007;170:121-8. doi: 10.1016/j.forsciint.2007.03.033

11. LeBeau MA, Montgomery MA, Brewer JD. The role of variations in growth rate and sample collection on interpreting results of segmental analyses of hair. Forensic Sci Int 2011;210:110-6. doi: 10.1016/j.forsciint.2011.02.015
12. Strote J, Lee JE, Wechsler H. Increasing MDMA use among college students: results of a National Survey. J Adolesc Health 2002;30:64-72. doi: 10.1016/S1054-139X(01)00315-9

13. Martins SS, Mazzotti G, Chilcoat HD. Trends in ecstasy use in the United States From 1995 to 2001: Comparison with marijuana users and association with other drug use. Exp Clin Psychopharm 2005;13:244-52. doi: 10.1037/10641297.13.3.244

14. Molinaro S, Siciliano V, Curzio O, Denoth V, Salvadori S, Mariani F. Illegal substance use among Italian high school students: trends over 11 years (1999-2009). PLoS ONE 2011;6:e20482. doi: 10.1371/journal.pone.0020482

15. Pedersen W, Skrondal A. Ecstasy and new patterns of drug use: A normal population study. Addiction 1999;94:1695706. doi: 10.1046/j.1360-0443.1999.941116957.x

16. Degenhardt L, Barker B, Topp L. Patterns of ecstasy use in Australia: Findings from a National Household Survey. Addiction 2004;99:187-93. doi: 10.1111/j.1360-0443.2003.00622.x

17. Chen WJ, Fu TC, Ting TT, Huang WL, Tang GM, Hsiao CK, Chen CY. Use of ecstasy and other psychoactive substances among school-attending adolescents in Taiwan: national surveys 2004-2006. BMC Public Health 2009;9:27. doi: 10.1186/1471-2458-9-27.

18. Tsanaclis LM, Edwards DM, Wicks JFC. Hair analysis for detection of drugs: a retrospective review of data obtained in the routine practice of a specialist laboratory; 39 th Annual International Meeting TIAFT 2001 Prague; 26-30 Aug 2001; Prague, Czech Republic. P.O73

19. Karačić V, Skender Lj. Hair testing for drugs of abuse. Coll Antropol 2003;27:263-9. doi: 613.83:616.594.1-074

20. Han E, Park Y, Yang W, Lee J, Lee S, Kim E, Lim M, Chung $H$. The study of metabolite-to-parent drug ratios of methamphetamine and methylenedioxymethamphetamine in hair. Forensic Sci Int 2006;161:124-9. doi: 10.1016/j. forsciint.2006.03.031

21. Karačić V, Skender Lj, Brčić I, Bagarić A. Hair testing for drugs of abuse: A two-year experience. Arh Hig Rada Toksikol 2002;53:213-20. PMID: 12557474

22. Martins LF, Yegles M, Thieme D, Wennig R. Influence of bleaching on the enantiomeric disposition of amphetaminetype stimulants in hair. Forensic Sci Int 2008;176:38-41. doi: 10.1016/j.forsciint.2007.06.023

23. Baeck SK, Han EY, Chung HS, Pyo MY. Effects of repeated hair washing and a single hair dyeing on concentrations of methamphetamine and amphetamine in human hairs. Forensic Sci Int 2011;206:77-80. doi: 10.1016/j. forsciint.2010.06.023

24. Musshoff F, Madea B. Analytical pitfalls in hair testing. Anal Bioanal Chem 2007;388:1475-94. doi: 10.1007/s00216-0071288-x

25. Musshoff F, Stamer UM, Madea B. Pharmacogenetics and forensic toxicology. Forensic Sci Int 2010;203:53-62. doi: 10.1016/j.forsciint.2010.07.011 


\section{Sažetak}

Evaluacija zlouporabe stimulansa amfetaminskog tipa putem analize kose: rezultati dvanaestogodišnjeg rada

Analiza kose pouzdan je način za detektiranje dugotrajnog konzumiranja ilegalnih droga, uključujući stimulanse amfetaminskog tipa u razdoblju od nekoliko tjedana do nekoliko mjeseci, ovisno o duljini kose koja se koristi za analizu. Od 2000. do 2012. u Institutu za medicinska istraživanja i medicinu rada analizirano je više od 600 uzoraka kose na prisutnost stimulansa amfetaminskog tipa. Vezani sustav plinski kromatograf/spektrometar masa koristio se za određivanje masenog udjela amfetamina, metamfetamina, 3,4-metilenedioksiamfetamina (MDA), 3,4-metilenedioksimetamfetamina (MDMA-Ekstazi) i 3,4-metilenedioksietilamfetamina (MDEA) u kosi. Uzorci kose uzimani su u Institutu, dostavljeni su poštom ili ih je treća osoba donijela u laboratorij. U većini slučajeva uzorkovanje i analiza kose obavljeni su anonimno. Dvadeset tri posto analiziranih uzoraka kose bilo je pozitivno na jedan ili više stimulansa amfetaminskog tipa. Najčešće je detektiran MDMA, a najčešća kombinacija stimulansa bila je amfetamin s MDMA. U Institutu se postupak za testiranje uzoraka kose na prisutnost stimulansa amfetaminskog tipa provodi više od 12 godina i smatra se pouzdanim načinom potvrde ponavljanog konzumiranja tih stimulansa. Naši rezultati mogu upućivati na trend zloporabe stimulansa amfetaminskog tipa među mlađom hrvatskom populacijom.

KLJUČNE RIJEČI: GC/MS; kvantitativno određivanje; MDMA; metamfetamin

\section{CORRESPONDING AUTHOR:}

Irena Brčić Karačonji, $\mathrm{PhD}$

Institute for Medical Research and Occupational Health, Ksaverska c. 2, POB 291, HR-10001 Zagreb, Croatia E-mail:ibrcic@imi.hr 